\title{
ESPACIOS DEVOCIONALES PARA LOS NEGROS EN EL SAN LUIS POTOSÍ VIRREINAL
}

\author{
J. Armando Hernández Soubervielle ${ }^{1}$ \\ El Colegio de San Luis, A.C.
}

\begin{abstract}
El presente artículo da cuenta de los espacios con que los negros - ya libres o esclavos - contaron para manifestar su devoción de forma particular en el San Luis Potosí virreinal. Da cuenta también de las vicisitudes por las que pasaron para obtenerlos y/o mantenerlos, toda vez que, al igual que muchos de ellos, estos espacios nunca contaron con la libertad que les hubiera permitido decidir sobre estos. Busca asimismo, rescatar del olvido la presencia de los hombres de raza negra en tanto miembros de una sociedad fuertemente jerarquizada, con corporaciones que los incorporaron en el tejido social y que demandaban una espacialidad específica. Los negros y sus espacios de devoción, se presentan para enriquecer la historiografía que versa sobre de aquel San Luis que perteneció a la monarquía española.
\end{abstract}

Palabras clave: Espacios devocionales; negros; Nueva España; siglos XVII-XVIII; arquitectura.

\section{AFRO DEVOTIONAL SPACES IN VICEREGAL SAN LUIS POTOSI}

The present article offers an account of the spaces with which persons of African descent — whether free or slavescounted to express their devotion in a particular way in viceregal San Luis Potosí. The author relates the vicissitudes that occurred in order to obtain and/or maintain them, as in the case of many of these people their spaces never enjoyed the freedom that would have allowed them to decide their destination. This text also serves to rescue from oblivion the presence of Afro men as members of a strongly hierarchical society with corporations that incorporated them into the social structure and demanded a specific spatiality. Men of African origin and their spaces of devotion are presented here to enrich the historiography of that San Luis once belonging to the Spanish monarchy.

Key words: Devotional spaces; Africans in Spanish-America; New Spain, $17^{\text {th }}-18^{\text {th }}$ Centuries; architecture.

Cómo citar este artículo / Citation: Hernández Soubervielle, J. Armando (2018): "Espacios devocionales para los negros en el San Luis Potosí Virreinal”. En: Archivo Español de Arte, vol. 91, núm. 364, Madrid, pp. 367-380. https:// doi.org/10.3989/aearte.2018.22.

\section{San Luis Potosí y la negritud}

El 4 de marzo de 1592 la historia del puesto de San Luis, habría de cambiar. Aquel día, por indicaciones del capitán Miguel Caldera, salieron del pueblo de San Miguel de Mexquitic, un grupo de hombres con la consigna de "tomar y catear minas" en lo que posteriormente serían los importantes yacimientos del Cerro de San Pedro. ${ }^{2}$ Este evento aceleraría el proceso de poblamiento español que se había empezado a dar en el valle de San Luis y en todo el septentrión novohispano.

Se ha establecido historiográficamente la estrecha relación entre el descubrimiento del mineral y la necesidad de una zona para beneficiarlo, como el detonante principal para la fundación

\footnotetext{
1 armando.hernandez@colsan.edu.mx / ORCID iD: http://orcid.org/0000-0003-4461-2765.

2 Velázquez, 1982, t. I: 501.
} 
del pueblo de San Luis. Los intereses mineros y comerciales que surgieron explican en gran medida por qué, tanto de la Nueva Galicia como de la Nueva España y en general de ese universo denominado monarquía hispánica, empezaron a llegar, prontamente, hombres nacidos en estas tierras, así como naturales de España, Portugal, Génova, Nápoles, Bruselas, Amberes, Grecia, pero también de África y el Caribe, ${ }^{3}$ quienes habrían de convertirse en vecinos del primitivo pueblo.

El arribo de afrodescendientes, forzados o no, para sumarse a las fuerzas laborales, a la tareas económicas o a las de servicio doméstico, implicaría primeramente un ajuste y enriquecimiento demográfico del pueblo ${ }^{4}$ y con ello, la necesidad de instituciones y espacios de vinculación, así como de diferenciación. La estratificada sociedad virreinal así lo requería.

Entre 1580 y 1650 se dio en el virreinato, merced al descenso demográfico de indígenas, un arribo masivo de negros, coincidiendo así con la fundación del pueblo ${ }^{5}$. La presencia de comerciantes negreros, muy temprano en San Luis, da cuenta de la demanda de esta "mercancía" en el pueblo Entre los más activos estaban Cristóbal López, Juan López Borandon, Gabriel Pastrana y Francisco López Enríquez, ${ }^{6}$ quien en 1613 vendió un importante cargamento de negros esclavos a mineros de San Luis por la necesidad de gente laboría que se demandaba en ese momento, ${ }^{7}$ lo que por supuesto nunca era suficiente, pues incluso las relaciones eclesiásticas hacían notar la necesidad de armazones de negros para que la minería no parara ${ }^{8}$. Tanta fue la demanda de estos hombres que un $40 \%$ de la fuerza laboral en las minas, en el primer tercio del siglo XVII, fue afrodescendiente ${ }^{9} \mathrm{y}$, si bien no existen datos demográficos que nos permitan realizar una tabla con el número exacto de negros en el pueblo, algunas relaciones eclesiásticas dan cuenta de la existencia de ellos y su comparación con respecto a la población española. Así, para 1619 se sabe que existían 1500 españoles en el pueblo, en contraparte de 700 pobladores, entre negros, mulatos e indios, señalando que estos últimos eran los menos, aunque sin precisar cifras ${ }^{10}$. Sumémosle las transacciones entre comerciantes, mineros y religiosos cuyos esclavos pasaban de mano en mano y de sitio en sitio. No abordaremos aquí esa otra cara de la moneda relativa a lo que significaba tener un negro en propiedad, pero la riqueza, el boato y ostentación pasaban también por lucir mercancías humanas. Pero también estaban los negros libres, quienes atraídos por la exención tributaria que implicaba vivir en frontera chichimeca o por las oportunidades que la propia minería y un comercio naciente ofrecían, habían llegado al pueblo. Hombres y mujeres irían apareciendo y dejando su impronta. Un caso emblemático por la movilidad social que refleja, es el de Antona Gallegos, mulata libre que fuera esposa de Pedro Hidalgo Meléndez, antiguo sacristán y portero de la primitiva iglesia de la Santa Veracruz y su cofradía ${ }^{11}$. Natural de Jerez de la Frontera, hija de negro y "morena", ${ }^{12}$ el 16 de junio de 1621, viuda ya, ante la fe del escribano Juan de Trujillo y Harria, dejó establecido que una casa de su morada se testara por sus mitades a la archicofradía de Nuestro Amo y a la de la Santa Veracruz ${ }^{13}$. Esto es, una mujer afrodescendiente en franca posesión de una casa y solar en lo que había sido la primera traza del pueblo de San Luis.

En cuanto a cifras, hemos dicho ya que no hay nada claro para finales del siglo XVI ni principios del XVII. Un padrón de 1643 dejó la cifra de 3450 almas en el pueblo, pero sin distinguir

\footnotetext{
3 Archivo Histórico del Estado de San Luis Potosí (AHESLP), Alcaldía Mayor de San Luis Potosí (AMSLP), Administrativo, 1593-1596, Caja 1, Exp. 10.

${ }^{4}$ Montoya, 2015.

5 Castañeda, 2012: 241.

6 Soto, 2003: 195-197.

7 Montoya, 2009: 87.

8 Relación del obispado de Michoacán por el obispo fray Baltasar de Covarrubias, O.S.A. Valladolid de Michoacán, 1619, Biblioteca del Palacio Real, Madrid, Ms. 2579, fs. 1 a 24 v.

${ }_{9}$ Montoya, 2015: 76.

10 Relación del obispado de Michoacán...

11 AHESLP, AMSLP, 1614.2, Caja 155, Exp. 26, ff. 1-15v. El caso de Antona y Pedro es interesante porque son ejemplos de integración entre europeos y africanos por vía matrimonial.

${ }^{12}$ Morales, 2014: 321.

13 AHESLP, AMSLP, 1674.3, Caja 415, Exp. 6, f. 3rv, junio 16 de 1621.
} 
"calidades". A finales del siglo tenemos por fin una idea más clara, pues sabemos que de las 3105 personas que habitaban la, ya ciudad, 880 eran negros y mulatos, ${ }^{14}$ Coincidiendo este momento con el de mayor evidencia de la presencia negra traducida en espacios de devoción. El siglo XVIII vería un descenso significativo de esta población y de las transacciones de hombres de esta raza, en parte porque no eran ya los asentistas portugueses sino comerciantes españoles los que llevaban el negocio, y porque la población se había ido mezclando cada vez más, creciendo la "mulatización" y el mestizaje ${ }^{15}$.

Con ello en mente, podemos entrar de lleno al asunto de los espacios religiosos destinados a los negros, ya que, como grupo inmerso en una sociedad a todas luces jerarquizada, ocupaban de corporaciones y espacios para poner en práctica su devoción.

\section{Espacios de sociabilidad, espacios físicos para la devoción}

Muy temprano en el siglo XVI, corporaciones, tales como las cofradías, estructuraron la sociedad de la América hispánica. Impulsoras de la fe recién implantada y espacios de convivencia e interacción, ${ }^{16}$ estas fraternidades se constituyeron en una fuente de cohesión y control social en razón de ser la única organización social no excluyente ${ }^{17}$. En estas asociaciones los negros habrían de encontrar un canal de inserción en la sociedad novohispana. Para el caso de San Luis Potosí, desde su fundación se contó con cofradías bajo el amparo del clero secular; como lo fueron la de la Santa Veracruz, la de Nuestra Señora del Rosario (1594) ${ }^{18}$ y la del Santísimo Sacramento $(1595)^{19}$. Estas cofradías se encontraban fundadas en la iglesia que hacía las veces de parroquia en los años fundacionales del pueblo, misma que a la postre sería conocida como de la Santa Veracruz ${ }^{20}$. En aquel edificio original se encontraban tres altares, uno dedicado a la Santa Veracruz y a San Blas, otro dedicado a Santa Lucía y uno más a San Cosme y San Damián. Sería en esta capilla que se establecería el primer espacio religioso para los negros.

Se pensaba que la antigua ermita de la Santa Veracruz pertenecía de los franciscanos y que estos, una vez mudados al lugar que en la actualidad ocupan, legaron la antigua construcción a los negros, pues como "infelices desheredados" que eran, "sin protector, iglesia ni cofradía", debían acogerse a lo sagrado de una u otra forma ${ }^{21}$. Nada más lejano a la realidad. Dicha iglesia no perteneció al cenobio franciscano, sino que estaba sujeta al clero secular, ni ésta terminó en manos de los negros a finales del siglo XVI. La historia del primer espacio devocional para los afrodescendientes es otra.

Tenemos que hilvanar de nuevo nuestro argumento con las cofradías. Hemos comentado ya el carácter cohesionador y de control de estas instituciones, pero ¿y qué decir de sus asientos? Toda cofradía ocupa de un lugar, tanto para mostrar arraigo como para guardar sus insignias, llevar a cabo sus juntas y hacer patente su religiosidad. Pero sucedía que, dada la pobreza de muchas de ellas, ese lugar simplemente no existía. Eso fue lo que pasó con la primera cofradía de negros que hubo en el pueblo.

Entre 1597 y 1598 el bachiller don Juan Bernal fundó la primera cofradía de negros y mulatos intitulada Nuestra Señora de la Soledad de los Morenos; la idea, en efecto, era constituir un

\footnotetext{
14 Montoya, 2009: 111, 118.

15 Montoya, 2015: 119, 127.

16 Mancuso, 2007: 17.

${ }^{17}$ Así, tanto castas, como indígenas, podían fundar sus cofradías, lo que no obstaba para que hubiera fuertes diferencias estamentales y jerárquicas entre éstas y las fundadas por españoles.

18 Archivo General de la Nación (AGN), Indiferente Virreinal / Cofradías y Archicofradías, Caja 0913, Exp. 11,

19 AHESLP, AMSLP, Protocolos, 1595, Caja 8, Exp. 7, f. 541v, noviembre 29 de 1595.

${ }^{20}$ Hernández, 2015b. Sería en 1611 que las cofradías del Rosario y del Sacramento se mudaron a la nueva iglesia parroquial, quedándose solamente en la capilla primigenia la cofradía de la Santa Veracruz.

${ }^{21}$ Montejano, 1972: 16-17.
} ff. 5-6v. 
espacio de religiosidad exclusivo para aquellas gentes "de color quebrado"; uno que los vinculara en el ceremonial y en el espacio de sociabilidad que la religión procuraba. Merece la pena detenerse un instante en lo que simbólicamente representaba el que la cofradía se hubiera cobijado al amparo de la devoción de la Soledad. Por medio de la advocación titular, las cofradías buscaban el amparo, la protección y el consuelo. Las celebraciones eran ocasión de júbilo, reflexión y también llanto (emoción estrechamente vinculada a la virgen de la Soledad y a la de los Dolores). Lo interesante es que esas expresiones emocionales no sólo eran una fuente de placer (descargo de conciencia o agradecimiento por el favor recibido), sino muestra misma de la cohesión social22. La soledad de los negros, en su forzado destierro los más de ellos, encontraba especial socorro en una devoción que bien representaba la condición social en la que se encontraban. Lo anterior, además, bajo la estricta vigilancia del clero secular.

Sin embargo, dicha cofradía, por la "calidad" de sus miembros, acusó una pobreza importante, a grado tal que, en 1605 aún no contaba con altar ni con constituciones. Para solucionar esto, el cura párroco, don Baltasar de Mesa, les procuró un corpus legal y asignó de fijo el altar de San Cosme y San Damián que estaba en la Santa Veracruz para que en él dijeran sus misas y conservaran sus insignias ${ }^{23}$. Esto tiene una lógica inmediata si consideramos que el padre podía otorgar tal permiso simplemente porque tenía jurisdicción sobre la capilla y porque, ante la necesidad de un colectivo existente, estaba en posibilidad de señalarles un espacio. No sabemos muy bien qué fue de este retablo, sólo que desaparecería de los inventarios con el decurso de los años. Muy probablemente este aparato se mudó junto con la cofradía a la nueva parroquia una vez que ésta fue habilitada entre 1609 y 1611 , cuando se concluyó la techumbre del nuevo edificio; época por la cual muchas otras cofradías comenzaban a instalarse en la nueva sede secular. Los santos hermanos, se vinculan a los negros a través del milagro de la pierna amputada a un negro para remplazar la pierna enferma de un hombre blanco. El anónimo donante africano, había sido medio para que los santos ejecutaran su prodigio. Pero el discurso simbólico va más allá, pues la callada agonía del esclavo para que su amo sanara, implicaba la incondicional abnegación de los primeros hacia sus dueños ${ }^{24}$. Esto es, que al hacer patronos de la cofradía a los santos Cosme y Damián, se incluía simbólicamente un discurso simbólico de sujeción y abnegación, necesarios en toda sociedad esclavista como la existente en el Imperio español.

Se ha dicho también que, con la llegada de los jesuitas a ocupar el terreno donde estaba edificada la Santa Veracruz, los negros se quedaron nuevamente sin amparo y protección y que apenas poseían una cruz que desplantarían bajo un mal portal junto a las Casas Reales y que, aledaño a la nueva parroquia levantaron una capilla muy humilde ${ }^{25}$. Salvo lo último, lo demás carece de veracidad y para llegar a ello tenemos que seguirle la pista a cada uno de los espacios referidos.

Lo importante de revisar la breve estancia que tuvieron los negros en la Santa Veracruz y la adjudicación de un altar para su cofradía, radica en el hecho de poder dar cuenta y razón de ese primer asiento devocional y que éste no sólo se trató de un espacio físico, sino de una fraternidad donde convergían ideas más abstractas, como la pertenencia y la cohesión. Ahora bien, con esta fundación, el vínculo de los negros con el clero secular comenzaba su relación, lo que resulta interesante considerar si se toma en cuenta que fueron los franciscanos los que más arroparon en sus altares a las cofradías de negros y mulatos a lo largo y ancho del virreinato ${ }^{26}$. En un San Luis Potosí donde los seráficos habían jugado un papel fundamental, no deja de llamar la atención que fueran los seculares quienes se hicieran con la tarea de procurar un espacio devocional a la población de origen africano.

22 Lutz, 2001: 32.

23 Velázquez, 1982, t. II: 415. Peña, 1979: 100.

Esto mismo sucedió en el altar destinado a San Cosme y San Damián, existente en la parroquia de la Santa Veracruz de México, donde se le dio acogida a la cofradía de la Exaltación de la Cruz de los Negros. Bazarte, 1989: 64.

${ }^{24}$ Fracchia, 2010: 139.

25 Montejano, 1972: 17.

26 Castañeda, 2012: 241. 
¿Qué pudo ser de aquella cofradía y su altar en la nueva parroquia? Intuimos que inicialmente el aparato fue colocado en uno de los tramos de la nave y que permanecería ahí hasta que, quizás a mediados del siglo XVII, a los negros les fue permitido construir una pequeña capilla aneja a la parroquia, en el terreno que era parte del cementerio. Si bien pocas, una de las primeras noticias que tenemos de una capilla para afrodescendientes data de 1652, cuando este espacio se menciona en el proceso que se siguió al indio mulero Francisco Acha por haber dado muerte a un mestizo ${ }^{27}$.

También de una causa criminal, esta de 1657 , se desprenden noticias acerca de la capilla de los negros. El día 24 de abril de aquel año, el negro José Hernández, esclavo de don Diego Salamanca, declaró que había asistido a misa a las siete de la mañana en la iglesia parroquial y que, habiendo "entrado en la capilla de los negros", vio "un cuerpo muerto, comido y sin cabeza", al que por su vestimenta lo había identificado como el de un indio que trabajaba para su $\mathrm{amo}^{28}$.

Importan de la declaración dos aspectos. Primeramente habla de un espacio y no de un altar que podríamos confundir como capilla; el afirmar "haber entrado" nos da certeza de ello. Segundo, el uso secundario que se le daba a este espacio, ya que servía como repositorio momentáneo de cadáveres de desconocidos, con miras a su identificación y reconocimiento si ello se ocupaba.

Una solicitud que hicieron los cofrades de la Santa Veracruz del cuerpo de un ajusticiado de nombre Mateo de la Cruz en 1668, para darle cristiana sepultura, nos da certeza de la ubicación de la capilla, ya que tal sería el destino de sus restos mortales: "en la capilla de los negros, junto a la parroquia" 29 .

Interesante sería saber cómo o con qué medios los negros construyeron una capilla anexa a la parroquia. Sabemos por algunas descripciones que más adelante comentaremos, que el espacio recibió poco mantenimiento y que terminó casi en ruinas hasta que fue rescatado por el alcalde don Martín de Mendalde, aunque sobre ello habremos de volver.

La capilla "de los negros", estaba bajo la advocación de Nuestra Señora de los Morenos (algunos autores han propuesto también el título de Nuestra Señora de África) ${ }^{30}$. Seguramente fueron sus limosnas las que permitieron la construcción, pero desconocemos el proceso constructivo y sus características, aunque a buen seguro, el espacio debió de estar constituido de material deleznable (adobe, bajareque y terrado) que, por económico, permitía su pronto levantamiento. Tampoco tenemos noticia de sus altares y de aquel retablo primitivo dedicado a San Cosme y San Damián nada volvemos a saber. Lo que sí, es que junto a los criminales que se llegaron a enterrar en esa capilla, yacían también los restos mortales de los negros, como lo atestiguan los casos del mulato libre Andrés Hurtado Cuin y su esposa, la negra libre Leonor María, quienes dejaron 11 pesos de limosna para ser sepultados en dicha capilla en 1640 y 1651 respectivamente $^{31}$.

Es hasta la llegada del alcalde don Martín de Mendalde que tenemos noticias concretas de la capilla. En mayo de 1674, cuando Mendalde entró en la ciudad, se percató que entre las Casas Reales y la parroquia se encontraba una "Santa Cruz bajo un mal portal"32. Para proteger la dignidad del santo madero, decidió se construyera una reja y cerca entorno suyo para que, de noche, no entraran personas en el portal ${ }^{33}$. La cruz permanecería así durante los siguientes meses, hasta que en 1675 decidió construir una capilla en la que se albergaría y veneraría la representación del Sanctum Lignum y que sería dedicada a una imagen del señor Ecce Homo de su propiedad.

Para comenzar la edificación, Mendalde costearía la obra de su propio peculio, comenzando ésta en $1676,{ }^{34} \mathrm{El}$ edificio correría desde las Casas Reales hasta la parroquia, abarcando parte del

27 AHESLP, AMSLP, 1652.2, Caja 345, Exp. 8, julio 1. ${ }^{\circ}$ de 1652.

28 AHESLP, AMSLP, 1657.2, Caja 359, Exp. 5, ff. 1-2, abril 23 de 1657.

29 AHESLP, AMSLP, 1660.2, Caja 370, Exp. 25, ff. 17-18v. Enero 13 de 1668.

30 Martínez, 2004: 180.

31 Martínez, 2017: 25, 27.

32 AHESLP, Ayuntamiento de San Luis Potosí (AYTO), Libros de Cabildo, 1672-1677, f. 633. Septiembre 9 de 1677.

33 AHESLP, AYTO, Libros de Cabildo, 1672-1677, f. 620. Enero 4 de 1677.

${ }^{34}$ AHESLP, AYTO, Libros de Cabildo, 1672-1677, f. 620v. Enero 4 de 1677. 
corral y osario de esta última. Considerando lo edificado, el retablo que adornaría su interior, un tribuna que dispuso para conectar capilla con Casas Reales así como las alhajas para el oficio divino. En otros trabajos se ha reflexionado acerca de lo que significó la obra de Mendalde tanto en lo urbano como en lo simbólico para la ciudad de San Luis Potosí, ${ }^{35}$ baste decir que el alcalde veía en la construcción de la capilla del Ecce Homo, un claro monumento a su paso por San Luis Potosí. Pero, lo que importa para el caso de los negros es que, al tiempo de ir hermoseando esta parte de la plaza principal, Mendalde se percató de una que podríamos llamar, "pequeña mancha", que afeaba su proyecto: la capilla de los negros.

Construida junto a la parroquia, el espacio destinado a la cofradía de negros y mulatos, no había recibido aderezo alguno desde su construcción; esto en virtud de la constante pobreza en la que se encontraba la corporación. Con la capilla mandada construir por Mendalde terminada, la cuadra se componía - de izquierda a derecha- de Casas Reales, capilla del Ecce Homo y parroquia, pero en medio de estas dos últimas la pequeña capilla de negros que, por su estado y ruina, afeaba la gran obra urbana del alcalde mayor. Incluso, para este momento, a la cofradía se le había privado de su espacio ya que sus imágenes habían sido trasladadas al interior de la parroquia y sus misas se rezaban en ésta. Las condiciones materiales de la capilla hacían imposible el culto divino.

La pequeña, pero significativa mácula, no podía ser pasada por alto, de forma tal que Mendalde le proporcionó a la cofradía el material excedente de la obra de la capilla dedicada al señor Ecce Homo, además de dinero y apoyo para obtener el permiso del juez eclesiástico para pedir limosna, de forma tal que, al poco tiempo, la de los negros también se había aderezado, en particular su frontispicio ${ }^{36}$.

El contar con las dimensiones de la cuadra poniente de la plaza principal, las medidas de la antigua parroquia, las de la capilla del señor Ecce Homo y la de las Casas Reales, nos ha permitido reconstruir lo que pudo ser espacialmente aquel recinto devocional de los negros en San Luis Potosí (figs. 1 y 2).

Poco les duraría el regocijo a los negros. Las fuertes lluvias que asolaron la región en el año de 1695 hicieron que tanto la capilla que había construido Mendalde como la de los morenos, se vinieran abajo. La parroquia se había deteriorado fuertemente y, las dos capillas o "salas", que servían como estribos del muro de la parroquia, "desfallecieron" por la corrosión que por todas partes las afectaban; la parroquia estaba al caerse y la gente no asistía al culto divino por el miedo a accidentarse,${ }^{37}$ todo esto terminaría por impactar el espacio de los negros.

Los albores del siglo XVIII trajeron consigo nuevos anhelos, siendo uno de ellos el construir una nueva y mejor parroquia. Las miras estaban puestas no sólo en mejorar un espacio que se había venido deteriorando, sino en conseguir el nombramiento de sede episcopal para San Luis Potosí, ${ }^{38}$ lo cual pasaba por mejorar primeramente la parroquia. Ese proyecto se ejecutaría y, con ello, tanto la capilla del Ecce Homo como la capilla de los negros, no volverían a ser levantadas en el sitio que otrora ocuparon. El nuevo proyecto establecía la necesidad de ampliar el crucero norte del edificio, justo en donde las capillas habían sido erigidas apenas unos años atrás.

Puesto que Mendalde había dejado al ayuntamiento por patrono de la capilla, poca o nada de oposición hubo para que aquella capilla no se reconstruyera, bastando mudar la imagen del Ecce Homo a la parroquia; en tanto que los negros, por carecer realmente de voz, nada pudieron hacer para reclamar se levantara de nuevo un espacio para su devoción. Esta situación nos genera una laguna documental ya que, a partir de este momento perdemos noticia de un espacio destinado para estos hombres. A buen seguro, los afrodescendientes fueron reubicados en alguno de los altares de la parroquia, volviendo así a sus humildes inicios.

Pasarían cerca de 40 años para que se perfilara un nuevo espacio para los negros en la ciudad. En octubre de 1742, el obispo de Michoacán, don Pablo Matos Coronado, se encontraba en la

\footnotetext{
35 Hernández, 2015a.

36 AHESLP, AYTO, Libros de Cabildo, 1672-1677, f. 622v. Enero 4 de 1677.

37 Informe sobre el deterioro del templo parroquial, febrero 15 de 1695, Archivo del Antiguo Obispado de Michoacán, Casa de Morelos (AAOMCM), Diocesano, Gobierno, Parroquias, Informes, 1695, Caja 9, Exp. 22, ff. 5.

38 Martínez, 2004: 86.
} 


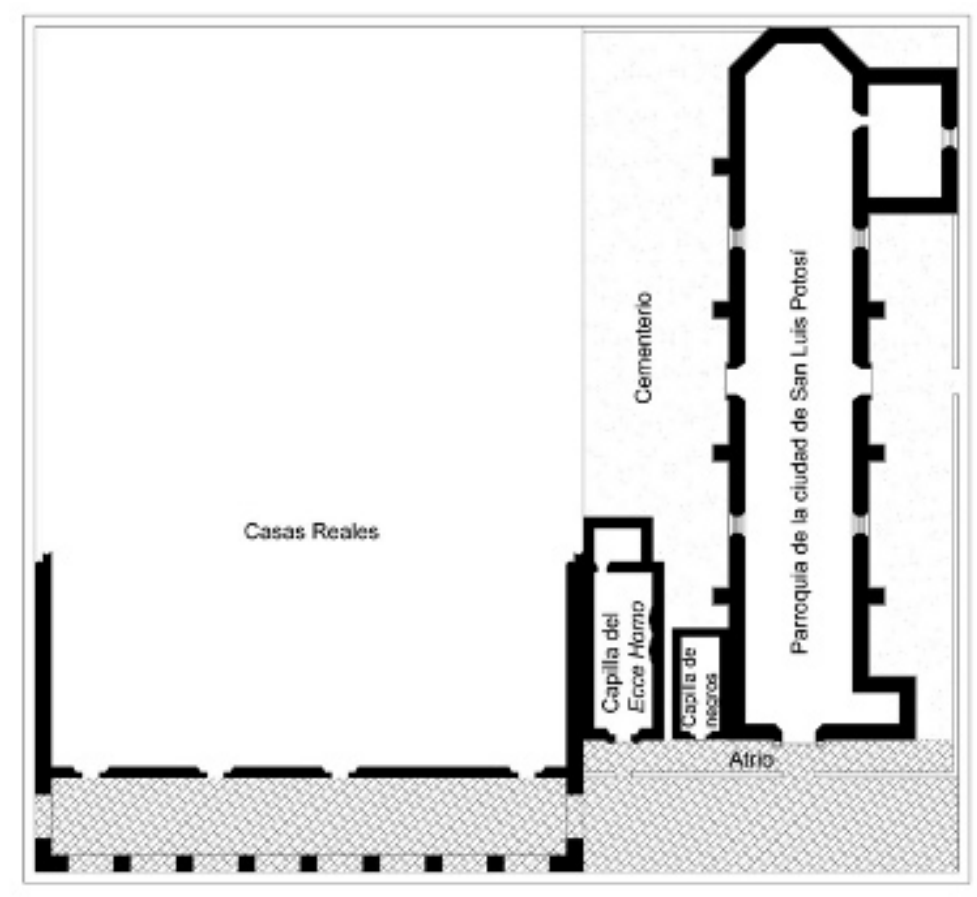

Fig. 1. Reconstrucción hipotética de la capilla de los negros hacia 1676. Armando Hdz. Soubervielle.

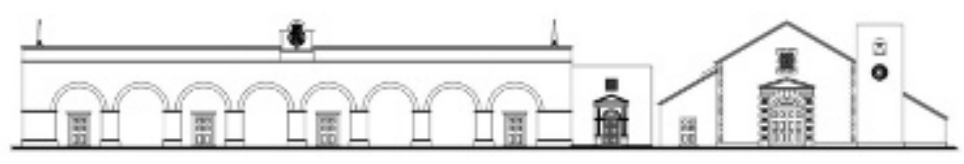

Fig. 2. Perspectiva hipotética de la capilla de los negros hacia 1676. Armando Hdz. Soubervielle.

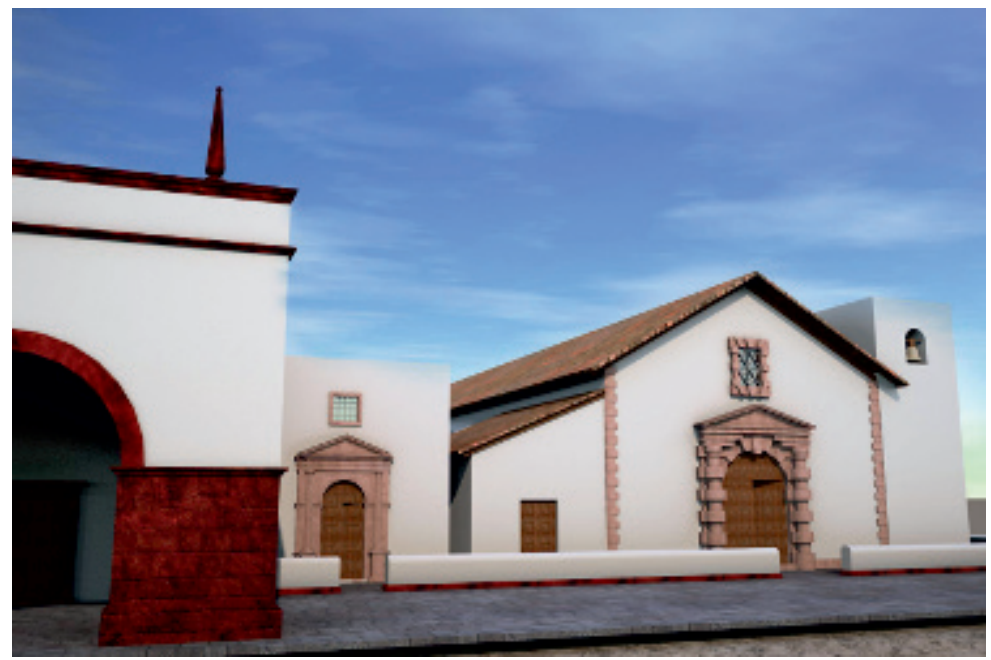

ciudad con la intención de arreglar de una vez por todas el grave problema que existía entre los regulares de la Compañía de Jesús y la cofradía de la Santa Veracruz. El conflicto era añejo y tenía que ver con las condiciones en que la cofradía y el clero secular habían acordado la donación del terreno a los jesuitas en 1624. Tanto el cura beneficiado como la cofradía (que por entonces era ya archicofradía al haberse anexado la cofradía de Nuestra Señora de los Dolores del 
gremio de sastres) estaban involucradas en el conflicto con los ignacianos, por lo que Matos Coronado, en un intento de "desembarazar" a los cofrades de la iglesia y colegio, decidió entre otras cosas, revocar el vínculo entre los de la Santa Veracruz y la cofradía de sastres. Para que lo anterior se ejecutara y no dejar en desamparo a la cofradía, se les prometió un altar fijo en la parroquia en el cual se veneraría una imagen nueva de la virgen de los Dolores que donarían los jesuitas ${ }^{39}$. Si la asignación no le parecía a los sastres, existía aún otra posibilidad: darles el retablo y mudarlo a la "capilla que se está fabricando en la calle de San Agustín con el título de Nuestra Señora del Rosario y la Salud" 40 . Esto resulta importante porque nos habla de una obra en proceso que supliría a la capilla de negros que había lindado junto a la antigua parroquia.

Sobre esta obra debemos comenzar diciendo que los terrenos para que se erigiera fueron donados por la congregación o hermandad de Nuestra Señora del Rosario que componían "los Pardos" - ya no la cofradía de Nuestra Señora de la Soledad - a través de uno de sus mayordomos, Estanislao Farfán (apodado "filigrana"), mulato libre que fungía como sacristán de la parroquia en 1737. Este mulato era famoso por su fervor, tanto que en la procesión que celebraba el paso de hospicio a convento del Carmen, se decía que el repicar de las campanas sólo se acallaba para "que se oyesen las loas de un pobre pero muy virtuoso mulato llamado Farfán" 41. Es gracias a un pleito con el convento de San Juan de Dios, que nos enteramos que el 22 de enero de 1737 la congregación había entrado en posesión de dicho solar y que en éste pretendían desde aquel momento, construirse una capilla ${ }^{42}$. Los juaninos alegaban ser los dueños del solar y pretendían frenar la obra que casi inmediatamente se había comenzado, "amontonando material" que con limosnas hechas a favor de la "Señora del Rosario" se habían juntado. Al mayordomo Victorio Ferrel se le conminó a desistir y frenar la obra en tanto se arreglaba el tema con los de la orden hospitalaria ${ }^{43}$.

Hubieron de pasar cinco años para que la obra se comenzara en toda forma. Ahora bien, existen algunas discrepancias cronológicas en la historiografía local: de acuerdo a Velázquez, el 5 de enero de 1743, el obispo de Valladolid de Michoacán, don Martín de Elizacoechea, concedió licencia para que se iniciaran los trabajos de edificación, obra que estaría bajo la dirección del bachiller don Ignacio Xavier de Contreras, ${ }^{44}$ quien a la sazón era el rector de la congregación ${ }^{45}$. Si consideramos que Matos Coronado afirma que la obra estaba en construcción en 1742, significa que previamente existía la licencia episcopal y que su obra comenzó años antes, tal y como se comprueba con el hecho de saber que el maestro alarife, el indio José Lorenzo, estaba participando hacia 1741 en la edificación de la suntuosa capilla del Rosario, que gracias al celo del bachiller Ignacio Contreras y de la Congregación de los Pardos se estaba levantando ${ }^{46}$.

Una vez concluida la obra, los negros volvieron a contar con un espacio - su espacio- de devoción, como antaño lo fuera junto a la parroquia. Nuevamente los restos mortales de los hombres y mujeres de "color quebrado", contarían con un lugar propio para descansar. Sin embargo, al depender del clero secular - al que siempre estuvieron vinculados como ya se ha visto- $\mathrm{y}$, al tener por rector al cura beneficiado, este espacio no nació del todo como una capilla exclusiva para negros, por lo cual se podían esperar una multitud de usos y acomodos que el propio clero estimara convenientes. Los negros contaban nuevamente, sí, con un espacio, pero como muchos de ellos, dicho espacio tampoco gozaba de entera libertad.

Una de estas adecuaciones, hecha en 1765, nos permite enterarnos del estado de este edifico y de algunas de sus características: En una visita realizada por Gerónimo López Llergo, se señala que junto a la Capilla de la Salud, se estaba construyendo una casa de piedad para que se

\footnotetext{
39 Hernández, 2015b.

40 Archivo Histórico Nacional, Madrid (AHN), Clero, Jesuitas, Libro 380, f. 57, octubre 5 de 1742.

41 Martínez, 1985: 81.

42 Velázquez, 1987, t. II: 89-90.

43 Velázquez, 1987, t. II: 92.

44 Velázquez, 1982, t. II: 415-416.

45 Velázquez, 1987, t. II: 90.

46 Martínez, 1985: 159.
} 


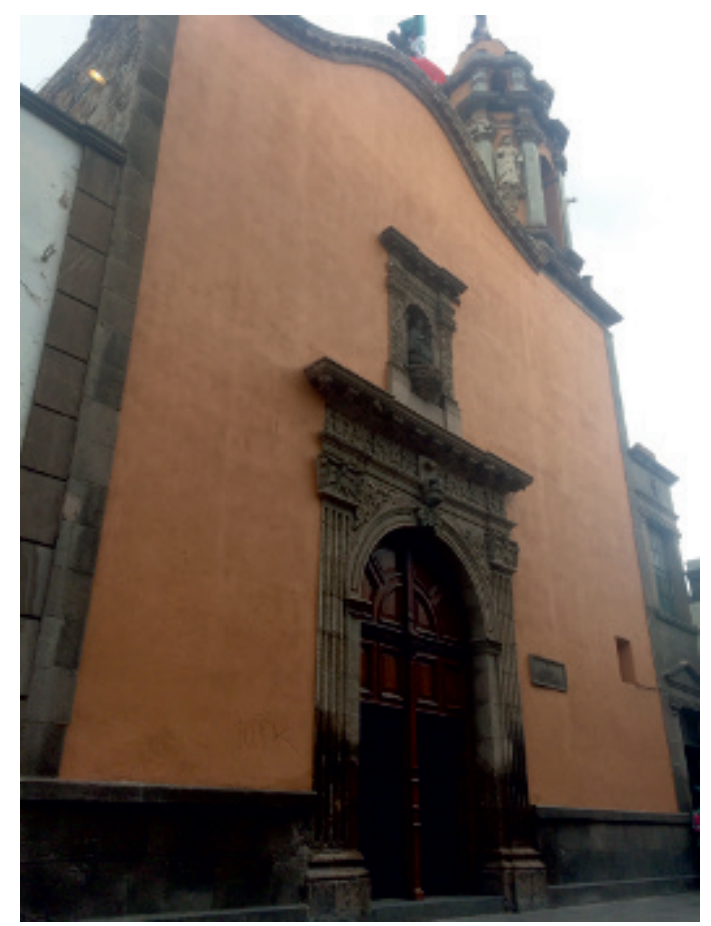

Fig. 3. Capilla de Nuestra Señora del Rosario. Armando Hdz. Soubervielle, 2017.

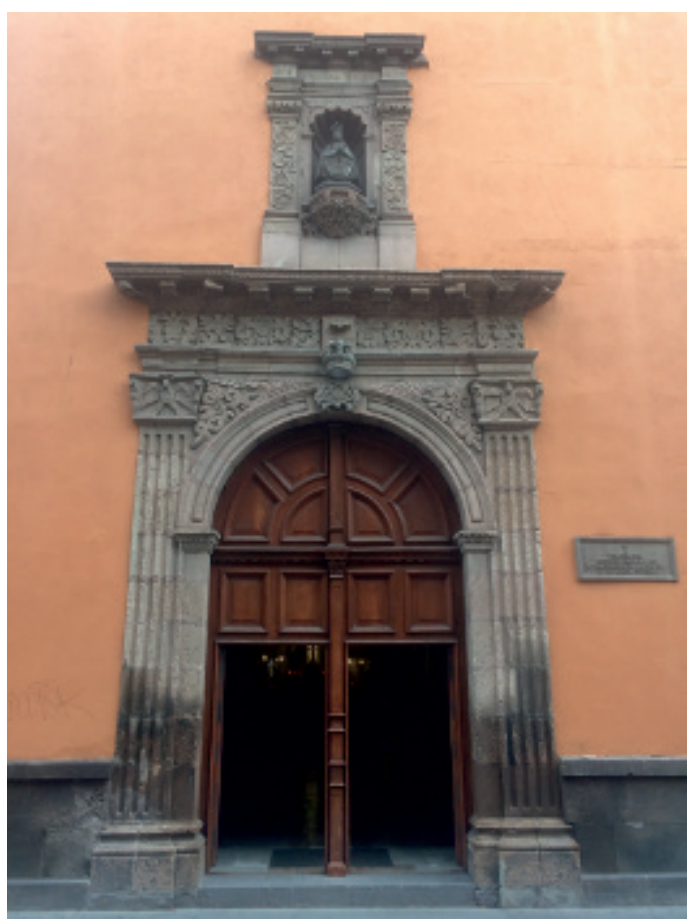

Fig. 4. Capilla de Nuestra Señora del Rosario. Armando Hdz. Soubervielle, 2017.

hospedaran y curaran pobres y enfermos de todas las castas. Dicha casa se haría en los terrenos pertenecientes a la capilla, lo que nos permite enterarnos de la existencia de una torre, pues se habla de su cubo; de pilares o estribos que soportaban la edificación en el costado sur; asimismo de una sacristía bien proporcionada que caía a un patio donde se hallaba la sala del sacerdote ${ }^{47}$.

Esta capilla permanecería en manos del clero secular hasta 1901, cuando le fue donada a los dominicos quienes, apenas un año después, tomaron posesión del antiguo convento juanino. El siglo XX sólo sería testigo de un paulatino deterioro de este espacio nacido para amparar a la negritud en San Luis...

La capilla, al ser el único vestigio de los espacios devocionales donde participaban directamente los negros en aquel San Luis Potosí virreinal, ocupa que analicemos, aunque someramente, sus características arquitectónicas.

El recinto (figs. 3 y 4 ) se encuentra ubicado en la calle que conecta las iglesias del Carmen y de San Juan de Dios. Su frontispicio es muy sencillo, aunque en su paramento destaca una portada de cantera labrada solucionada a manera de arco triunfal de muy buena factura en el que se aprecian dos pilastras con cuatriglifos rematadas por pelícanos hendiendo su pico en el pecho — simbolizando el sacrificio de Cristo- haciendo las veces de capiteles; representación simbólica ésta que asimismo encontramos en las iglesias del Carmen, San Sebastián y San Francisco, y que también tuvo la iglesia de la Compañía ${ }^{48}$ en la ciudad. Una corona remata la clave del arco y sobre ésta una cruz dominica superpuesta que recuerda la breve estancia de los de santo Domingo en este espacio. El nicho que remata el frontis, compuesto por otro arco de triunfo con una peana en la base, con querubes tenantes por adorno, conserva una escultura de Nuestra Se-

${ }^{47}$ Casa de piedad para pobres y enfermos, AAOMCM, Diocesano; Justicia; Testamentos, capellanías y obras pías; Obras pías; 1765, Caja 1146, Exp. 120, ff. 27.

48 Hernández, 2005. 


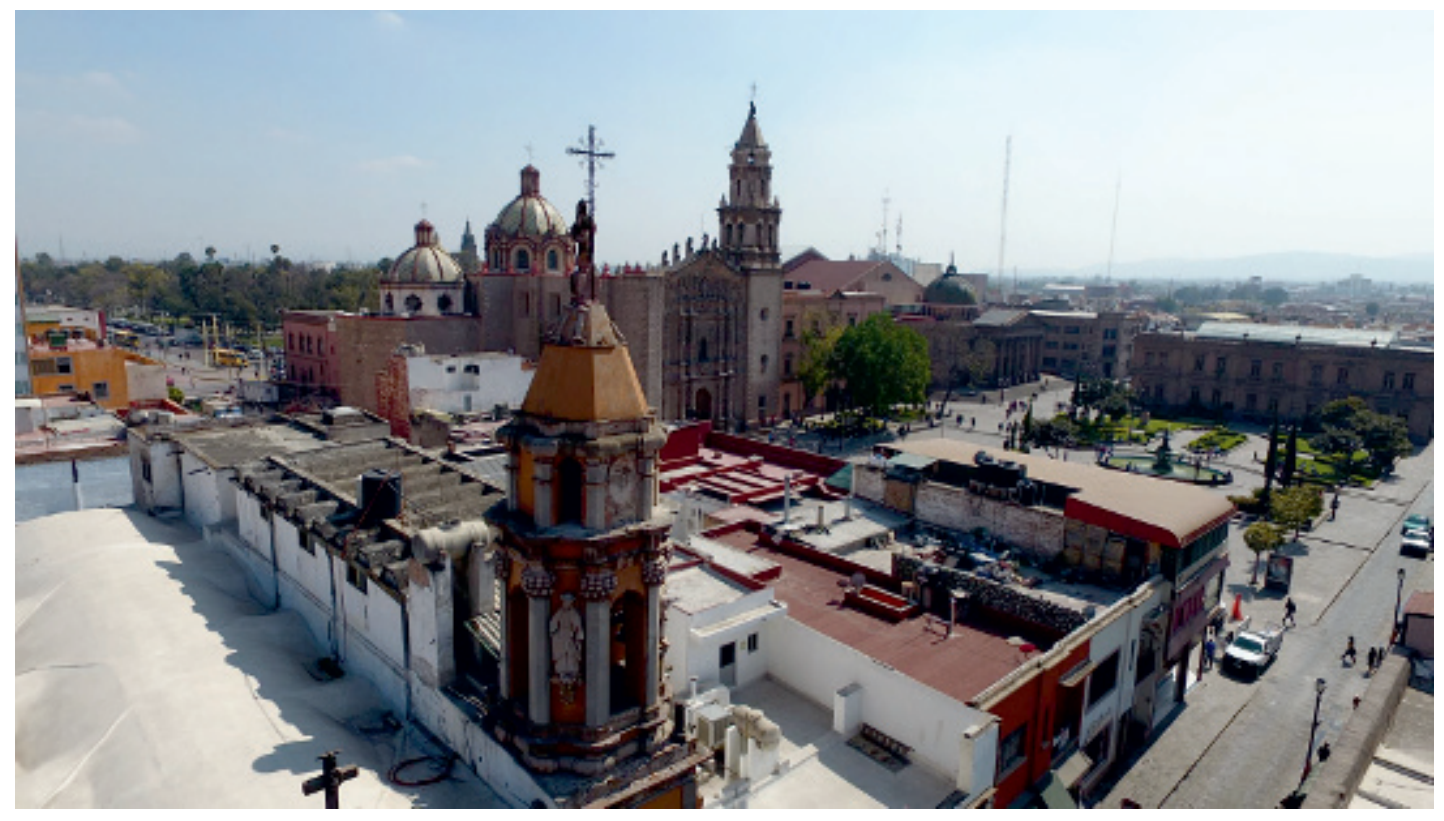

Fig. 5. Torre de la capilla de Nuestra Señora del Rosario. Eduardo Briones, 2017.

ñora de la Salud. Por su ornamento y disposición arquitectónica, este nicho nos recuerda el de la capilla de Nuestra señora de Loreto del conjunto jesuita de la ciudad. Es decir, que con sus limitaciones y aún en su sencillez, la capilla de la Salud había tomado los recursos simbólicos y arquitectónicos de otras iglesias de la ciudad.

Se ha cuestionado sobre si la linternilla de la torre de esta capilla (fig. 5), por el año en que se fecha su construcción (1742-43), es el antecedente de la torre del Carmen (acabada en 1767 como reza la inscripción pintada en su cubo), es decir, una torre con remate en forma de prisma, hermanándose a su vez con la torre de Santo Domingo en la ciudad de México ${ }^{49}$. No hay forma de comprobar lo anterior toda vez que carecemos de los documentos de la construcción de la capilla; sin embargo, la noticia de 1765 en la que se refiere el cubo de esta torre, nos invita a pensar que en efecto, la de los negros es previa a la levantada por los del Carmelo (fig. 6), con lo cual, indirectamente estarían dejando un modelo arquitectónico a seguir.

De su interior sabemos de la existencia de un retablo dorado del siglo XVIII que fue sustituido por uno acorde al gusto neoclásico, lo mismo que su pintura mural ${ }^{50} \mathrm{y}$ poco más, siendo una de las víctimas más notorias de la furibunda acometida neoclásica. Dentro se conserva un cuadro de Nuestra Señora del Rosario con los santos Francisco de Asís y Domingo de Guzmán, obra ésta de la segunda mitad del siglo XVIII; una Adoración de los reyes de mediados del siglo XVIII y en el coro varios lienzos de los apóstoles en forma de óvalos, que también corresponden a aquel período ${ }^{51}$. Manuel Muro cita la existencia de un cuadro de las Ánimas del purgatorio, ${ }^{52}$ aunque de éste no queda rastro alguno. De la presencia de los negros (al igual que en el resto de la ciudad) nada ha llegado a nuestros días, salvo el negro Baltasar en el cuadro, apenas como un eco de aquella lejana presencia.

\footnotetext{
49 De la Maza, 1969: 62.

50 De la Maza, 1969: 62.

51 Gómez, 1991: 49.

52 Muro, 1910: t. II, p. 4.
} 
Fig. 6. Torre del templo del Carmen. Armando Hdz. Soubervielle, 2017.

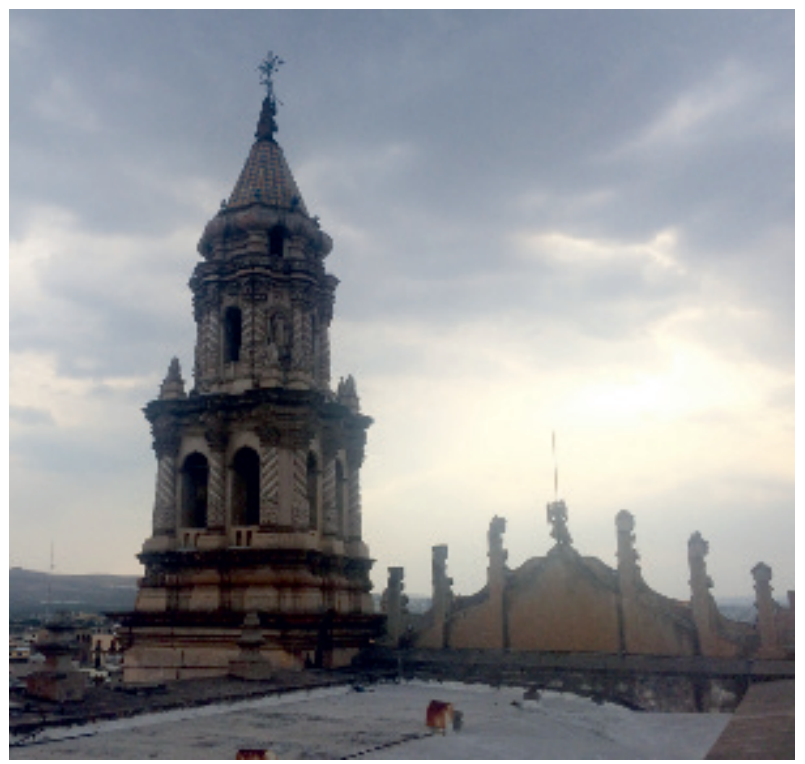

\section{La ciudad como espacio de los negros}

Nos hemos remitido hasta aquí a los espacios propiamente establecidos para los negros, pero no debemos olvidar que la ciudad misma constituía un espacio para que los afrodescendientes se manifestaran también como una comunidad con fuerte presencia. Los negros formaron parte de la transformación urbana, como ya hemos hecho notar, al donar terrenos, casas, huertas y lo que ello conllevó: cambiar la fisonomía de la ciudad. Pero remitámonos aquí a una fiesta que, al ser de carácter religioso y corporativo, es también un motivo para hablar de un espacio de manifestación de los negros: la fiesta de Corpus Christi. Desde muy temprano en el pueblo de San Luis, se constituyó la procesión de Corpus, donde las cofradías salían con solemnidad por las calles acostumbradas ${ }^{53}$ y en la que la de los negros tuvo su lugar cuando se fundó a principios del siglo XVII. Esta solemnidad, como en todo el orbe hispano, permitía reafirmarse en tanto corporación, así como hacer manifiesta su antigüedad y sus preeminencias simbólicas ${ }^{54}$. Ya en el siglo XVIII, a la procesión de cofradías durante la celebración de Corpus, se le sumarían cuatro parejas de figuras denominadas "Gigantes", que representaban una de indios, una de moros, otra de blancos europeos y una más, sí, de negros. En 1746 el ayuntamiento declaró que cada pareja representaba las cuatro partes del mundo adorando la Eucaristía ${ }^{55}$. Así, los negros quedaban representados por los gigantes y participaban a través de la procesión de su cofradía, de una devoción que tomaba las calles de la ciudad como escenario, ampliando así su presencia material y simbólica.

\section{A manera de conclusión}

La Independencia fue - al menos para los negros en San Luis Potosí- discrecional, ya que no obtendrían su libertad en $1821,{ }^{56}$ sino hasta $1827^{57}$. Para entonces las cofradías y las congre-

53 Hernández, 2015.

54 Véase por ejemplo el caso de la cofradía de negros en Sevilla. Moreno, 1997: 116-117.

55 Martínez, 2017: 23.

56 Por más de que, para ese momento existiera hipotéticamente un solo negro esclavo en la ciudad.

57 Martínez, 1981: 4. Es de resaltar el año, ya que mientras que en México la figura jurídica de la esclavitud fue abolida por el supremo Gobierno General de la República en 1829, en San Luis Potosí el Congreso del Estado la abolió 
gaciones ya se habían diluido, al menos las más débiles, como lo fueron la cofradía de Nuestra Señora de la Soledad de los morenos y la congregación de Nuestra señora del Rosario de los pardos. Ya no había necesidad de un espacio diferenciado puesto que, aunque tarde, los negros habían pasado a ser unos más; proceso al que el mestizaje había abonado desde mucho tiempo antes. Quizás por ello no nos hayan llegado vestigios claros de la presencia negra y sus espacios de devoción, teniendo que hilar finamente con las pocas hebras que saltan de la urdimbre.

Lo anterior no nos impide lanzar otras preguntas. Por ejemplo, ¿qué pasó con las imágenes que complementaban dichos espacios?, ¿estarían representados San Benito de Palermo o Santa Ifigenia en los altares perdidos de la capilla de los negros junto a la parroquia y aquellos de la capilla de la Salud? Si se considera que fueron las únicas imágenes negras usadas en los altares novohispanos, ${ }^{58}$ quizás esto sea posible; luego entonces ¿dónde quedaron aquellas representaciones? En la actualidad existe en el templo de San Francisco, en el tercer tramo arquitectónico, a la izquierda, una escultura de bulto y vestir de San Benito de Palermo sobre un pedestal de madera. La talla representa al santo negro sin mayores atributos que su color y su hábito franciscano y si consideramos sus características formales, podemos inferir que esta representación no pudo estar en un posible altar dentro de la capilla de la Salud, menos aún en la desaparecida capilla de los negros, siendo por tanto obra moderna, ya desvinculada de los espacios virreinales propiamente.

De Santa Ifigenia no tenemos noticias de un posible culto o devoción en San Luis Potosí. Lo único que aparece en nuestro rastreo documental es la mención de un sitio de ganado en Santa María del Río, denominado "Santa Ifigenia", y esto ya en el siglo XVIII ${ }^{59}$. Es decir, ningún rastro documental o material que vincule a los negros con la devoción a la santa africana, a diferencia, por ejemplo, del fastuoso retablo dedicado a Santa Ifigenia, tallado por Juan de Astorga en 1766, para la iglesia de la Merced (hoy de la Compañía) en la ciudad nueva de Guatemala.

Por otro lado, nos podríamos aventurar a considerar que, si bien existieron espacios devocionales para los negros en el San Luis virreinal, también hubo imágenes que, puestas en retablos o altares subsidiarios, no exclusivos para los descendientes de África, sí los contemplaban al incluir dentro de su batería de advocaciones a los santos de color moreno, y si no a los santos, al menos representaciones alusivas a su raza (caritas, querubes, amorcillos morenos), pero tampoco han llegado a nuestros días. ¿No existieron? Quizás sí, pero acaso yacen bajo nuevas capas de pintura, pues frecuentemente a lo largo de los siglos XIX y el XX, muchos retablos fueron puestos, por los padres que los custodiaban, en manos inexpertas para su restauración, y quienes, sin ningún sentido - o con mucho tal vez-, terminaban por cubrir los rostros negros con tonos albaricocados, perdiéndose así el carácter universal que estos aparatos tenían ${ }^{60}$. Sin ir más lejos y como muestra, está el "blanqueado" que sufrió el Cristo de la Santa Veracruz existente en la iglesia de la Compañía de Jesús, aquí en San Luis Potosí, hace apenas unos cuantos años, a instancias del cura encargado, siendo que avellanados eran los tonos originales de la imagen.

el 29 de agosto de 1827. Más aún, una novena de artículos componían el decreto que entraría en vigencia el 16 de septiembre de ese año (fecha simbólica sin duda alguna), siendo el noveno de estos el que indicaba que todo aquel que pisara territorio potosino en calidad de esclavo, quedaría libre.

58 García, 2012: 241.

59 AHESLP, AMSLP, 1761.1, Caja 601, Exp. 25, 18 de abril de 1761.

${ }^{60}$ Ya desde el siglo XVII esto pasaba. El caso del "blanqueado" de algunas devociones es representativo de esto, como lo fue el caso de la virgen de Loreto (advocación cuya tez es morena de origen): Apoyados en la tesis de que la virgen de Loreto había sido siempre blanca y se había ennegrecido con los humos de las candelas que desde siempre la habían alumbrado, los jesuitas decidieron "blanquear" la imagen de la virgen de Loreto que llegaría a México a finales del siglo XVII y cuyo culto en adelante se expandiría en tierras novohispanas. Más allá, sin embargo, de esta justificación a todas luces simplista, está el hecho de haber blanqueado la imagen "por tenerse en estos reinos por vil el color denegrido, como propio de esclavos y gente vil", de acuerdo al padre Miguel Venegas, biógrafo del padre Zappa, quien dio cuenta de la dedicación de la Santa Casa de Loreto en Tepotzotlán. Crudo razonamiento que nos habla de un factor socio-racial que impactaba en todos los ámbitos y esferas de la sociedad novohispana. Sobre el tema véase: Alcalá, 2008: 171-193. 
Hablar del Cristo de la Santa Veracruz, nos permite por último, hilvanar este trabajo con otras representaciones que, aunque ajenas a los propósitos de este escrito - porque implican otro tipo de aproximación - debemos abordar por sus matices: es el caso de los Cristos negros. Referencias a Cristos Negros las tenemos también del siglo XIX, aunque su procedencia es muy posiblemente del XVIII. En particular nos referiremos al señor de Esquipulas, de origen guatemalteco y que tanta acogida tuvo en el norte, merced su introducción a través del Camino Real de la Tierra Adentro. Para el caso que nos ocupa basta mencionar la existencia de un par de Cristos negros en el hospital y templo de San Juan de Dios. Aunque la relación que da cuenta de esta advocación es algo tardía (1811), no deja de ser necesario mencionar su presencia tanto en altares como en imágenes peregrinas ${ }^{61}$. Sin embargo, se ha demostrado que en gran medida el impacto de estos Cristos fue mayor en la población indígena ${ }^{62}$ que en la propia población afrodescendiente, por lo que insistimos, resulta necesario mencionar su existencia en altares locales a manera de representaciones de hombres de piel oscura, mas no como expresión de una devoción propiamente negra.

La llegada de negros a San Luis Potosí comenzó siendo constante y en abundancia a finales del siglo XVI y en los albores del siglo XVII, sin embargo; se fue diluyendo, como en toda la Nueva España, poco a poco. Pero sus necesidades devocionales estaban ahí, presentes todo el tiempo, fueran pocos los habitantes de raza negra; por ello resulta necesario comenzar a esclarecer cuáles fueron los espacios con que contaron para llevar a cabo sus prácticas religiosas pero también de cohesionamiento e identificación. Cuál fue su batería de devociones y qué circunstancias rodearon la concreción de los espacios (altares, capillas, iglesias) que les fueron facilitados.

Con sus recursos, claramente limitados, y sin la fuerte presencia que en otras latitudes lograron gente de su misma raza (hemos mencionado en varias ocasiones en este trabajo, por ejemplo, Guatemala), los negros en San Luis Potosí fueron haciéndose de espacios donde depositar su devoción. Comenzando por un retablo cedido para dar sitio a su cofradía, pasando por contar con una capilla que, gracias a las aspiraciones de un alcalde mayor alcanzó cierta dignidad constructiva - hasta que las aguas quisieron-, y hasta ser dueños sin serlo, de una nueva capilla, los negros buscaron acogerse a espacios que les diera identidad y pertenencia. Más allá de la necesidad religiosa, el desarraigo de la tierra de nacimiento y, más aún, la libertad arrancada en la mayoría de los casos, eran los componentes que hacían imperativo el que estos hombres buscaran un espacio de coincidencia e identificación. Hoy nos toca reconstruir esa parte de la historia urbano-arquitectónica, incluso artística, porque forma parte de una realidad que hoy, por carecer de referentes inmediatos y claros, pareciera que no existió; y que nos sirve en parte de recordatorio de esa deleznable, pero histórica, figura jurídica que fue la esclavitud, a través de la cual llegara gente de color negro a estas tierras, gente cuya raza, cuya sangre, corre por las venas de muchos hombres y mujeres del llamado Nuevo Mundo, encontrando en ellos el espacio final que tanto anhelaron y que hoy recuperamos.

\section{BIBLIOGRAFÍA}

Alcalá, Luisa Elena (2008): "Blanqueando la Loreto mexicana. Prejuicios sociales y condicionamientos materiales en la representación de vírgenes negras". En: La imagen religiosa en la Monarquía hispánica. Usos y espacios (estudios reunidos y presentados por María Cruz de Carlos, Pierre Civil, Felipe Pereda y Cécile Vincent-Cassy. Prólogo de Antonio Bonet Correa). Madrid: Casa de Vélazquez, pp. 171-193.

${ }^{61}$ A la muerte del prior del convento-hospital de San Juan de Dios en 1811, se elaboró un inventario que comienza refiriendo entre otras, "una imagen peregrina del Señor de Esquipulas, con resplandor y corona de plata sobredorada" además de un "Altar del Santo Cristo [de] Esquipulas. Chiquito, dorado, la imagen del señor original, muy hermosa. Corona y resplandor de plata"; acompañábanlo un san Joaquín y santa Ana, san José, la virgen de la Candelaria, su niño Dios y un san Cristóbal. AHESLP, AYTO, Libros de Cabildo, 1811, ff. 115, 119v-120.

${ }^{62}$ Véase para el caso Pacheco, 2005. 
Bazarte Martínez, Alicia (1989): Las cofradias de españoles en la ciudad de México (1526-1869). México: Universidad Autónoma Metropolitana.

Bechtloff, Dagmar (1993): "La formación de una sociedad intercultural: las cofradías en el Michoacán colonial". En: Historia Mexicana, Vol. 43, 2 (170), octubre-diciembre, 1993, México, pp. 251-263.

Castañeda García, Rafael (2012): "Devociones y construcción de identidades entre los negros y mulatos de la Nueva España (s. XVIIII)". En: Fundación Visión Cultural, Memoria del VI Encuentro Internacional sobre el Barroco. Imagen del Poder. Bolivia: Visión Cultural, pp. 241-247.

De la Maza, Francisco (1969): El arte colonial en San Luis Potosí. México: UNAM, Instituto de Investigaciones Estéticas.

Fracchia, Carmen (2010): “El esclavo negroafricano en las imágenes españolas de los santos Cosme y Damián”. En: La esclavitud negroafricana en la historia de España. Siglos XVI y XVII. Granada: Comares, pp. 127-149.

Gómez Eichelmann, Salvador (1991): Historia de la pintura en San Luis Potosí, 2 tomos. San Luis Potosí: Archivo Histórico del Estado de San Luis Potosí.

Hernández Soubervielle, J. Armando (2005): "La iconografía perdida del Sagrario". En: Universitarios Potosinos, Nueva Época, Año 1, 4, Agosto de 2005, San Luis Potosí, pp. 24-27.

Hernández Soubervielle, J. Armando (2015a): El tamaño de las aspiraciones. El alcalde mayor don Martín de Mendalde como agente en la transformación de San Luis Potosí entre 1674 y 1677. San Luis Potosí: Gobierno del Estado de San Luis Potosí, Secretaría de Cultura.

Hernández Soubervielle, J. Armando (2015b): El madero y la piedra. Historia, arte y devenir de la cofradía de la Santa Veracruz y sus iglesias en el San Luis Potosí virreinal. México: El Colegio de San Luis / UASLP.

Lutz, Tom (2001): El llanto. Historia de las lágrimas. México: Taurus.

Mancuso, Lara (2007): Cofradias mineras: religiosidad popular en México y Brasil, siglo XVIII. México: El Colegio de México.

Martínez Rosales, Alfonso (1981): "San Luis Potosí, tierra de libertad”. En: Boletín cultural de radio Universidad XEXQ, V época, 14, octubre de 1981, UASLP, San Luis Potosí, pp. 3-5.

Martínez Rosales, Alfonso (1985): El gran teatro de un pequeño mundo. El Carmen de San Luis Potosí, 1732-1859. México: El Colegio de México, Universidad Autónoma de San Luis Potosí.

Martínez Rosales, Alfonso (2004): La Catedral de San Luis Potosí. San Luis Potosí: Kaiser Editores.

Martínez Rosales, Alfonso (2017): “África en el crisol racial de San Luis Potosí”. En: Confluencias de culturas. San Luis Potosi y la presencia de África. San Luis Potosí: Secretaría de Cultura, Gobierno del Estado de San Luis Potosí, pp. 21-33.

Montejano y Aguiñaga, Rafael (1972): El palacio municipal de la ciudad de San Luis Potosí. San Luis Potosí: Academia de Historia Potosina (Biblioteca de Historia Potosina, Serie Estudios, 3).

Montoya, Ramón Alejandro (2009): San Luis del Potosí novohispano. Origen y evolución sociodemográfica de un real de minas. San Luis Potosí: UASLP / CCSyH.

Montoya, Ramón Alejandro (2015): El tráfico de esclavos africanos en San Luis Potosí. Siglos XVII y XVIII. San Luis Potosí: Gobierno del Estado de San Luis Potosí, Secretaría de Cultura.

Morales Bocardo, Rafael (2014): Diccionario biográfico de antiguos pobladores de San Luis Potosí, 1592-1666. San Luis Potosí: El Colegio de San Luis / Archivo Histórico del Estado de San Luis Potosí.

Moreno, Isidoro (1997): La antigua hermandad de los negros de Sevilla. Etnicidad, poder y sociedad en 600 años de historia. Sevilla: Universidad de Sevilla / Junta de Andalucía.

Muro, Manuel (1910): Historia de San Luis Potosí. San Luis Potosí: Imprenta Moderna de Fernando H. González.

Pacheco Rojas, José de la Cruz (2005): "El Cristo negro en la tradición del camino Real de Tierra Adentro". En: Boletín oficial del Instituto Nacional de Antropología e Historia, 79, Nueva Época: julio-septiembre de 2005, México: pp. 21-35.

Peña, Francisco (1979): Estudio histórico sobre San Luis Potosí (Introducción, transcripción, notas e índice de Rafael Montejano y Aguiñaga). San Luis Potosí: Biblioteca de Historia Potosina, Serie Estudios, 17, Academia de Historia Potosina.

Soto Salazar, Limonar (2003). La extranjería en la Nueva España, el caso de los portugueses en los centros mineros en el norte del virreinato: Circunstancias sociales y políticas. Tesis de maestría. San Luis Potosí: El Colegio de San Luis.

Torres Vega, José Martín / Salazar González, Guadalupe (2011): Documentos para la historia del espacio habitable en el Archivo Histórico Casa de Morelos. San Luis Potosí: Universidad Autónoma de San Luis Potosí.

Velázquez, Primo Feliciano (1982): Historia de San Luis Potosí, 4 tomos. San Luis Potosí: Archivo Histórico del Estado, Academia de Historia Potosina.

Velázquez, Primo Feliciano (1987): Colección de documentos para la historia de San Luis Potosí, 4 tomos. San Luis Potosí: Archivo Histórico del Estado de San Luis Potosí.

Fecha de recepción: 03-X-2017

Fecha de aceptación: 19-I-2018

Archivo Español de Arte, vol. XCI, n. ${ }^{\circ}$ 364, pp. 367-380, octubre-diciembre 2018

ISSN: 0004-0428, eISSN: 1988-8511, https://doi.org/10.3989/aearte.2018.22 